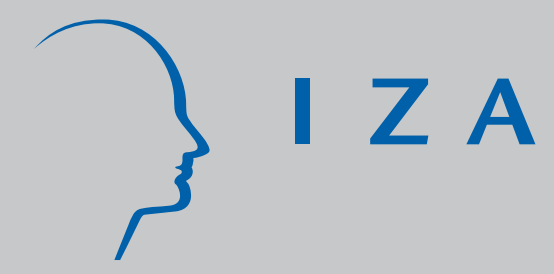

IZA DP No. 4000

Happiness and Economic Growth: Does the Cross Section Predict Time Trends? Evidence from Developing Countries

Richard A. Easterlin

Onnicha Sawangfa

February 2009 


\title{
Happiness and Economic Growth: Does the Cross Section Predict Time Trends? \\ Evidence from Developing Countries
}

\author{
Richard A. Easterlin \\ University of Southern California \\ and IZA \\ Onnicha Sawangfa \\ University of Southern California
}

Discussion Paper No. 4000

February 2009

\author{
IZA \\ P.O. Box 7240 \\ 53072 Bonn \\ Germany \\ Phone: +49-228-3894-0 \\ Fax: +49-228-3894-180 \\ E-mail: iza@iza.org
}

Any opinions expressed here are those of the author(s) and not those of IZA. Research published in this series may include views on policy, but the institute itself takes no institutional policy positions.

The Institute for the Study of Labor (IZA) in Bonn is a local and virtual international research center and a place of communication between science, politics and business. IZA is an independent nonprofit organization supported by Deutsche Post Foundation. The center is associated with the University of Bonn and offers a stimulating research environment through its international network, workshops and conferences, data service, project support, research visits and doctoral program. IZA engages in (i) original and internationally competitive research in all fields of labor economics, (ii) development of policy concepts, and (iii) dissemination of research results and concepts to the interested public.

IZA Discussion Papers often represent preliminary work and are circulated to encourage discussion. Citation of such a paper should account for its provisional character. A revised version may be available directly from the author. 
IZA Discussion Paper No. 4000

February 2009

\title{
ABSTRACT
}

\section{Happiness and Economic Growth: Does the Cross Section Predict Time Trends? Evidence from Developing Countries}

\begin{abstract}
Based on point-of-time comparisons of happiness in richer and poorer countries, it is commonly asserted that economic growth will have a significant positive impact on happiness in poorer countries, if not richer. The time trends of subjective well-being (SWB) in 13 developing countries, however, are not significantly related to predictions derived from the cross sectional relation of happiness to GDP per capita. The point-of-time comparison leads to the expectation that the same absolute increase in GDP per capita will have a bigger impact on SWB in a poorer than a richer country. In fact there is no significant relation between actual trends in SWB and those predicted from the cross sectional relationship. Nor is a higher percentage rate of growth in GDP per capita significantly positively associated with a greater improvement in SWB. In the developing countries studied here a greater increase in happiness does not accompany more rapid economic growth. These conclusions hold true for two measures of SWB that are separately analyzed, overall life satisfaction and satisfaction with finances. The two SWB measures themselves, however, typically trend similarly within a country, providing mutually supporting evidence of the trend in well-being.
\end{abstract}

JEL Classification: I31, D60, O5, O10

Keywords: happiness, economic growth, developing countries

Corresponding author:

Richard A. Easterlin

Department of Economics, KAP 300

University of Southern California

Los Angeles, California 90089-0253

USA

E-mail: easterl@usc.edu 
Little is known about happiness trends in the developing world. As a result, point-oftime comparisons between richer and poorer countries have typically been used to infer the likely course of happiness as GDP per capita rises. In this paper we bring together some of the limited evidence available on happiness in the developing world to examine whether trends over time are consistent with expectations based on cross sectional data. The developing countries are of special interest, because, according to the cross sectional comparisons, this is where economic growth would be expected to have its biggest impact on happiness. As it turns out, for the limited number of countries studied here, we find that the actual trends do not conform to those predicted by the cross sectional relationship.

We examine three specific questions: (1) What is the nature of happiness trends in the developing countries? (2) Does the commonly observed international cross sectional pattern of diminishing marginal utility of income predict the time trend in happiness? (3) Are higher rates of economic growth typically accompanied by more positive trends in happiness? We start with no preconceptions as to what the answers should be. Our interest is factual: to find out what the evidence is on these questions.

Studies of time trends in happiness in developing countries are virtually non-existent due to the limited and fragmentary nature of the available data. In the economics literature the most notable exception is a recent paper by Stevenson and Wolfers (2008). This study is commendable for its effort to mobilize a wide range of data to assess the happiness-growth relation, not only cross sectionally, but in time series as well. The time series analysis suffers, however, from, among other things, a failure to distinguish short from long-term relationships between happiness and GDP per capita, as will be discussed in the Methods section below. Outside of economics, there is a time series study by two quality-of-life specialists, Michael 
Hagerty and Ruut Veenhoven (2003) which, like the Stevenson and Wolfers paper, claims to find that happiness is positively associated with economic growth. This study has been critiqued by Easterlin (2005). (See also the reply by Hagerty and Veenhoven 2006). Finally, political scientist Ronald Inglehart and his collaborators in an analysis of World Values Survey data for recent decades report that "happiness rose in 45 of 52 countries for which substantial time series data were available," (Inglehart, Foa, Peterson and Welzel 2008, p. 264). As will be explained in the next section, this inference appears to result from an upward bias in the happiness measure on which the authors' conclusion relies. ${ }^{1}$

Our criterion for including a country to study happiness trends is that there be at least three comparable observations on subjective well-being spanning at least ten years; the average period spanned is actually about 16 years. This is a short time series for studying happiness. In the original time series study of happiness and economic growth, Easterlin (1974, p.110) found that, when comparing identical happiness questions, there was an increase in happiness in the United States from 1946 to 1956-57, followed by a decline to 1970, with a negligible net change over the entire period. The rise and fall observed in the United States over more than two decades suggests that even a ten- or fifteen-year period may fail to give a valid indication of the long-term trend. But even when we set minima as low as a ten-year period and comparable observations at three, we are left with fairly few developing countries - a total of only thirteen. This small number is somewhat compensated for by the fact that most are quite populous, and several have very high rates of economic growth. Indeed, four (Brazil, China, Japan, and South

\footnotetext{
${ }^{1}$ Analysts sometimes try to infer time series change by comparing the responses to "ladder-of-life" questions of the type asked in the recent Gallup World Poll to Hadley Cantril's (1965) results. To assume the recent responses are comparable to Cantril's is questionable. Before presenting respondents with the ladder-of-life question, Cantril's interviewers conducted a lengthy in-depth interview probing the respondents' concerns about the best and worst of all possible worlds (see Cantril 1965, pp. 22-24 and Easterlin 1974, pp. 91-92). The recent ladder-of-life questions have no counterpart to this lengthy preamble.
} 
Korea) have the distinction of being among the thirteen "success stories" of economic growth recently featured in a World Bank Report (Commission on Growth and Development 2008). Happiness depends on many factors (Bruni and Porta 2005; Frey and Stutzer 2002; Layard 2005). Generalizations about growth and happiness in developing countries, however, have typically been based on bivariate cross sectional comparisons of national measures of subjective well-being and per capita income. A succinct example of inferring time trends of subjective well-being for developing countries from a bivariate multi-country cross section appears in the valuable survey volume by two of the leading economists in the study of the economics of happiness:

Comparing across countries, it is true that income and happiness are positively related and that the marginal utility falls with higher income. Higher income clearly raises happiness in developing countries, while the effect is only small, if it exists at all, in rich countries (Frey and Stutzer 2002, p. 90).

Hence, in testing here such generalizations against time series evidence we too employ a bivariate methodology. Some analysts look at happiness in relation to the absolute amount of change in income; others, the percentage change. In the analysis below, we look at both.

In keeping with much of the literature the term happiness has been used to this point as a proxy for measures of subjective well-being (SWB) in general. The following analysis is based specifically on two measures of SWB, overall life satisfaction and satisfaction with finances. Although satisfaction with finances is less comprehensive than overall life satisfaction, one might expect it to be even more closely related to economic growth and thus an even better measure to test the happiness-growth relationship. Most importantly, by using two measures we are able to gauge whether they provide consistent answers to our three questions. In what 
follows, the term "subjective well-being" is used when referring to the two measures either separately or together.

\section{Data and Measures}

The principal data set is the World Values Survey (WVS), conducted in an increasing number of countries throughout the world in five waves: 1981-84, 1989-93, 1994-99, 1999-2004, and 2005-2007 (World and European Values Surveys Four-Wave Integrated Data File 2006; World Values Survey 2005 Official Data File V.20081015, 2008). Most of the developing countries included here were first surveyed in wave 2, but four (Argentina, Japan, South Korea, and Mexico) were covered in wave 1. A second major source is the Latinobarometer, conducted almost annually since 1995. For the six Latin American countries studied here - Argentina, Brazil, Chile, Mexico, Peru, and Venezuela - we rely on the Latinobarometer once it is available rather than the WVS, because of its fuller time series coverage. Two African countries, Nigeria and South Africa, are included. For South Africa, besides the WVS, there is a separate survey, the South African Quality of Life Trends Study commissioned to MarkData (hereafter SA MarkData) that provides a check on the WVS data. ${ }^{2}$ Five Asian countries are studied - China, India, Japan, South South Korea, and Turkey. For China two other survey sources, Gallup and the Asiabarometer are used to check the WVS. For Japan the primary series comes from the "Life in Nation" surveys. These surveys start in 1958 when Japan's GDP per capita, at 11 percent of the U.S. level in 2000, put it well within the developing bloc. The series extends through 2007, and is complemented by the WVS and a survey conducted by the Cabinet Office

\footnotetext{
${ }^{2}$ Special thanks go to Professor Valerie Møller of Rhodes University, Grahamstown, South Africa for providing tabulations of these data (that are not in the public domain) and valuable help regarding the comparability over time of the survey questions. Professor Møller has published extensively on quality of life in South Africa (see, e.g. Møller 1998, 2001, 2007).
} 
of Japan and kindly provided by Takayoshi Kusago covering the period 1978-2005 (Kusago 2007) ${ }^{3}$. The three surveys for Japan all terminate at a point when Japan's GDP per capita is upwards of 80 percent of the U.S. 2000 level, and thus span the widest range of growth experience covered here.

In the Japanese "Life in Nation" surveys there are several changes in the survey question between 1958 and 2007 (Hirata 2001; Stevenson and Wolfers 2008). Stevenson and Wolfers 2008, Table 5 gives a valuable digest of these data. We therefore divided the series into three segments that we analyze separately, Japan 1 (1958-1969), Japan 2 (1970-1991), and Japan 3 (1992-2007). The 11-year Japan 1 series comprises two shorter segments that we pool in order to satisfy our 10 year minimum criterion, using a dummy variable to account for the difference in response level attributable to the change in survey question. The WVS data for Japan (19812005), used in the analysis of satisfaction with finances, are labeled Japan 4.

The GDP data are those of the World Bank 1975 onwards (World Development Indicators Online 2008). Those for Japan prior to 1975 are based on a backward extrapolation of the World Bank series using the Penn World Table (Heston, Summers, and Aten 2006).

We date the observations on subjective well-being here, not at the actual survey dates, but to match the annual GDP observations that they most likely reflect. The GDP data are for calendar years while the SWB surveys typically relate to a single month or span only a few months. If a survey is conducted early in a year it would clearly be meaningless to link it to a GDP estimate covering the entire twelve months of the same year. Our procedure, therefore, is as follows. An SWB survey conducted within the first four months of a year, say, January April 1991, is linked to1990 GDP; a mid-year survey, conducted in the period May through August 1991 is compared to the GDP average of 1990 and 1991 and dated 1990.5; and a survey

\footnotetext{
${ }^{3}$ The Kusago series is used here in Appendix B as a check on the "Life in Nation" series.
} 
conducted in the latter part of the year, September-December 1991, is compared with 1991 GDP and dated 1991.

In the WVS life satisfaction and satisfaction with finances are measured on a response scale ranging in integer values from 1 (= dissatisfied) to 10 (= satisfied). The specific question for each subjective well-being measure used here is given in Appendix A.

We do not use the 4-category happiness measure from the WVS, except for India from wave 3 onward. The 10-response categories of the other two measures have the obvious advantage of greater sensitivity, but there is another reason for not using the happiness measure. In wave 2, the happiness question that was asked differs from that in later waves, and as a result, happiness diverges markedly from the other two SWB measures in its direction of change between waves 2 and 3 . This is particularly noticeable for the transition countries of central and eastern Europe for which a number of studies concur in the finding that the economic collapse in these countries was accompanied by a substantial decrease in subjective well-being (Easterlin 2009, EBRD 2007, Guriev and Zhuravskaya 2008, Llekes 2006, Sanfey and Teksoz 2007, Saris and Andreenkova 2001, Veenhoven 2001). In most of these transition countries, the average happiness answers rise from wave 2 to wave 3 of the WVS despite marked declines in life and financial satisfaction. Similarly, in all but one of the developing countries studied here, the happiness measure increases between waves 2 and 3 while the other two measures are almost always consistent with each other in direction of change, sometimes moving up together, sometimes down together.

The reason for the increase typically shown in the WVS happiness measure between waves 2 and 3 appears to be a "primacy" bias resulting from a change in the instruction accompanying the happiness question. In wave 2 , interviewers were instructed to alternate the 
order of response choices from one respondent to the next. Thus respondent 1 would be presented with choices ranging from "very happy" down to "not at all happy", while respondent 2 would be presented with "not at all happy" first. There are a number of survey studies demonstrating a tendency for respondents to favor earlier over later choices (Belson 1966, Chan 1991, Schuman and Presser 1981, pp. 56-77). In wave 2, therefore, half the respondents would have been more inclined toward less happy choices by virtue of being presented with the more negative options first. In wave 3, the "very happy" option appears first, and the instruction to alternate response options no longer appears. Hence happiness responses in wave 3 would tend to be biased upward relative to wave 2, a movement consistent with the positive between-wave changes almost universally observed in the happiness measure in both the transition and developing countries.

For overall life satisfaction there is also a bias problem, one that would tend to reduce life satisfaction in waves 3 and 4 compared to the earlier and later waves. In this case it is a "focusing bias", due to placing the question on financial satisfaction before that on overall life satisfaction in waves 3 and 4 (cf. Stevenson and Wolfers 2008). However, the question on financial, as opposed to life satisfaction appears to be comparable across waves in terms of both content and context. Both life and financial satisfaction typically exhibit similar directions of change between waves 2 and 3, suggesting that the bias in the question on life satisfaction, to the extent it exists, is not as serious as that in the happiness measure.

A paper by Inglehart, Foa, Peterson and Welzel (2008) proposes a substantive reason for the disparate time series movements in happiness and life satisfaction in the WVS. ${ }^{4}$ The authors suggest that the two measures reflect different determinants, the former, political conditions, and

\footnotetext{
${ }^{4}$ Helliwell and Putnam (2004) find somewhat different results for happiness versus life satisfaction in relation to a variety of social capital variables, but their analysis, unlike that of Inglehart and his collaborators, is cross sectional and multivariate.
} 
the latter, economic circumstances, citing specifically the experience of the transition countries of central and eastern Europe. In their interpretation "many ex-communist countries experienced democratization accompanied by economic collapse, resulting in rising happiness and falling satisfaction" (Inglehart, Foa, Peterson, and Welzel 2008, p. 277). Aside from the issue of statistical bias in the happiness measure, two pieces of evidence may be noted that call into question the argument that happiness moves differently from life satisfaction, because it is affected by democratization and life satisfaction is not.

As has been mentioned, in the transition countries of central and eastern Europe happiness typically increases between waves 2 and 3 of the WVS, but life satisfaction declines. Thanks to a question included in the Eurobarometer surveys in these countries, it is possible to test directly whether democratization explains the rise in happiness. The question is: "On the whole, are you very satisfied, fairly satisfied, not very satisfied, or not satisfied at all with the way democracy works in (your country)?"5 There are twelve transition countries included in both waves 2 and 3 of the WVS, and happiness increases in nine of the twelve. If the rise in happiness is due to democratization, a regression for all twelve countries of the change in happiness on the change in satisfaction with democracy should yield a positive slope coefficient. Actually, the regression yields a negative, though not statistically significant, coefficient. For two of the three countries that have the highest increase in happiness between waves 2 and 3, satisfaction with democracy declines. For two of the three countries in which happiness declines between waves 2 and 3, satisfaction with democracy increases. These results do not support the hypothesis that the movement in happiness is a result of democratization.

\footnotetext{
${ }^{5}$ For five countries the period spanned by the question is the same as that for the WVS happiness question; for the other seven the period covered by the question differs by one year from that to which the happiness question refers.
} 
Democratization may, however, temporarily affect happiness, but contrary to the view in the Inglehart et al article it affects life satisfaction similarly. There are almost no surveys like the WVS which ask both happiness and life satisfaction questions, but the SA MarkData survey for South Africa does. In May 1994, one month after the country's first democratic election, a survey was conducted that included questions about both happiness and life satisfaction. Here, for both measures is the percentage of the black population in the top two (out of five) categories at that time and the corresponding percentages at the two adjacent dates when similar surveys were conducted:

$\begin{array}{lccc} & \underline{1988} & \underline{1994} & \underline{1995} \\ \text { Happiness } & 32 & 80 & 39 \\ \text { Life satisfaction } & 37 & 86 & 45\end{array}$

Note how by both measures the well-being of blacks soared at the time of the election. But as Valerie Møller (2007, p. 248) observes: “[P]ost-election euphoria was short-lived. Satisfaction levels have since returned to ones reminiscent of those under the former regime." This return is registered by both SWB measures. Moreover, the magnitude of rise and fall is virtually identical for the two measures. This evidence suggests that democratization may temporarily affect subjective well-being, but this effect appears not only in happiness but in life satisfaction as well.

The Latinobarometer, used here together with the WVS for all six Latin American countries, also has comparability problems. The response categories for life satisfaction in the first two surveys (1997 and 2000) differ from those in subsequent surveys; hence the observations for the first two years are not used here. Also, the 2006 Latinobarometer data on financial satisfaction are omitted. In this case, a focusing bias occurred in 2006, because of the placement before the financial satisfaction question of a new question involving comparison with 
one's parents' situation that tended to bias upward the subsequent response on financial

satisfaction. $^{6}$

\section{Methods}

We compute the long-term growth rate of SWB by regressing it on time, taking as our period of analysis for each country the longest time span available. The long-term growth rate of GDP per capita is computed from the GDP per capita values at the start and end of the period covered by the SWB observations. When more than one data set is available for SWB, as in the case of the Latin American countries, we compute a pooled regression with a dummy variable to identify the different data set. Growth rates for both SWB and GDP are per year; the change in SWB is measured in absolute terms, that in GDP per capita, in percentage terms.

In taking long periods for analysis the purpose is specifically to distinguish the longer from the shorter-term relationship between SWB and GDP per capita. There is ample evidence that short term fluctuations in SWB are positive correlated with macroeconomic conditions. This is nowhere more apparent than in the massive economic collapse and subsequent recovery of the

\footnotetext{
${ }^{6}$ In the Latinobarometer the questions preceding the family economic situation question in 2005 and 2006 were: 2005. In the following twelve months, do you think that, in general, the economic situation of the country will be much better, a little better, the same, a little worse, or much worse than now? 2006. Do you think you have a job much better, a little better, the same as, a little worse, or much worse than your father did?

The response categories are identical for the two questions, so we computed for each country the mean response to each of the questions on a scale from 5 (much better) to 1 (much worse). We hypothesize that the shift to the 2006 question invoking a comparison of one's personal economic situation (one's job) with one's father's situation would put the respondent in a more favorable context to respond to the next question on one's current family economic situation than the 2005 question about the country's general economic outlook. The evidence confirmed this. In every one of 17 Latinobarometer countries the 2006 question requiring comparison with one's father elicited a mean response much higher than the 2005 question on the country's economic outlook, the answer averaging 0.9 points on the 1-5 scale. Moreover, the more favorable context invoked by the 2006 comparison with one's father resulted in more favorable response to the following question on one's family's economic situation. In 14 of the 17 countries there was an increase from 2005 to 2006 in the assessment of one's own economic situation, the average increment being about 0.1 points on a 1-5 scale. If one compares the 17 countries, one finds that the magnitude of the 20052006 increase in one's family's economic situation was significantly positively correlated with the magnitude of the 2005-2006 increase between the immediately preceding questions. We are grateful to Malgorzata Switek for carrying out this analysis.
} 
transition countries, but it is also evident in developed countries (Di Tella, MacCulloch, and Oswald 2001; Easterlin 2009; Guriev and Zhuravskaya 2008; Sanfey and Teksoz 2008). This shorter term positive association between fluctuations in SWB and GDP per capita should not be mistaken for the longer-term relation. Imagine, for example, two series one of SWB and one of GDP per capita, exhibiting synchronous sawtooth movements but those in SWB are around a horizontal trend line, while those in GDP per capita are about a positive trend. The short-term relationship between the growth rate of SWB and that of GDP per capita is positive, but the longer-term one is not.

If data with shorter and longer time spans for different countries are pooled, the shorter term positive relationship will tend to dominate a regression of SWB on GDP per capita. This is because short term growth rates of GDP per capita, both positive and negative, are larger (disregarding sign) than long term growth rates; hence the short-term rates are more likely to be the outlying observations and disproportionately affect the regression results.

An example of the failure to distinguish the short-term from the long-term relationship is the widely-publicized Stevenson and Wolfers (2008) paper that seeks to establish a positive relation between SWB and economic growth. In the part of their time series analysis that uses WVS data they estimate regression relationships like those done here between the change in life satisfaction and that in GDP per capita. They report the results of three "short first differences" and three "long first differences" regressions after eliminating WVS countries whose data they consider noncomparable over time (Stevenson and Wolfers 2008, Figure 15). The time spans of the "short first differences" regressions - typically five to six years - are too brief to identify the long-term relationship between SWB and GDP per capita. Of their three "long first differences" regressions only two have a significant positive coefficient. The significant positive coefficient 
for the waves II to IV regression (based on observations for 32 countries) is due to the inclusion of eleven transition countries, whose data particularly reflect the concurrent collapse and recovery of SWB and GDP per capita in these countries. If the transition countries are omitted from the regression, the slope coefficient is no longer significant. ${ }^{7}$ The significant positive coefficient for the waves I to IV analysis, based on seventeen countries, is due to the inclusion of one transition country, Hungary, with low growth in GDP per capita and a negative change in life satisfaction, and one developing country, South Korea, with very high growth in GDP per capita (it is offscale in their diagram) and high growth of life satisfaction. Among the other 15 countries, all of which are developed, there is no significant relation between the change in life satisfaction and that in GDP per capita. Thus, the positive association between the change in life satisfaction and that in GDP per capita reported by Stevenson and Wolfers rests almost entirely on the positively correlated V-shaped movement of the two variables during the post-1990 collapse and recovery in the transition countries. The slope of a regression line of life satisfaction on time passing through both the contraction and expansion phases in these countries is not significant in 10 of the 11 countries for which data are available (Easterlin 2009 forthcoming).

As mentioned, the WVS response scale for the two SWB questions used here ranges in integer values from 1 (= dissatisfied) to 10 (= satisfied). In other surveys included here, the response options are typically categorical, not numerical. In keeping with the usual practice in the literature, we have assigned integer values to each category from 1 (= the worst response option) up to the number corresponding to the best response option (e.g., 4 if there are four

\footnotetext{
${ }^{7}$ In re-doing the Stevenson and Wolfers' analysis we have converted both variables to a per year basis, because the interval between two given waves sometimes differs among countries. The effect on the results is negligible.
} 
response categories). We then compute the mean SWB from the integer responses for all respondents for each year that data are available.

Because the WVS satisfaction questions are on a 1-10 scale, while the non-WVS questions are on a 1-4 or 1-5 scale, we rescale the WVS responses to conform to the non-WVS scale. In rescaling the WVS to a 1-4 response scale, for example, we assume a WVS response of 10 corresponds to a non-WVS response of 4, a WVS response of 1 to a non-WVS response of 1 , and make a linear transformation using the formula:

$$
y=0.3333 x+0.6667
$$

where $\mathrm{y}=\mathrm{SWB}$ on the non-WVS scale, and

$$
\mathrm{x}=\mathrm{SWB} \text { on the WVS scale. }
$$

In the regression results in the analysis below the slope coefficients are those based on the rescaled WVS responses.

The WVS surveys are imperfect. In the preceding section we noted that the wording or context of the SWB questions sometimes changes over time, and concluded that the disparate change between waves 2 and 3 in happiness compared with life and financial satisfaction was due to a primacy bias. For this reason, we chose to focus our analysis on life and financial satisfaction.

Another problem is that for some countries the geographic coverage of the surveys changes over time. Sometimes sample weights are provided to adjust for variations in sample coverage, but weights are not given regularly enough to yield time series comparable for our purpose.

A valuable summary based on WVS documentation of shifts in survey coverage is given by Stevenson and Wolfers (2008, Appendix B). Their criterion for including a WVS survey in 
their analysis appears to be that the survey must be nationally representative. As a result they discard a number of surveys for seven of the countries studied here. Although a nationally representative survey is clearly preferable, it seems premature to dismiss other surveys as unusable. Invariably, when the WVS surveys are not nationally representative, they cover the more literate and urbanized segments of the population. These are precisely the groups that are most likely to be experiencing the income benefits of economic growth. Hence if economic growth is raising subjective well-being, it is these population groups that one would expect to show the improvement in SWB most clearly.

The real problem for comparability over time arises when the survey coverage changes, typically to a nationally representative survey. We try to minimize the effects of such shifts in several ways, depending on the nature of the available data. For two countries, Argentina and Chile, we use only the earlier WVS surveys that appear to be comparable over time in geographic coverage; these surveys cover about 70 percent of the population. For two other countries, Mexico and Nigeria, where the survey coverage is shifting, especially in regard to coverage of the rural population, we base our analysis on the SWB means for the population living in places of 100,000 population or more, those likely to be covered fairly consistently. Finally, for two other countries, China and South Africa, we have independent surveys by other organizations that provide support for the time series change in SWB reported in the WVS. Of the seven countries included here whose surveys are largely or wholly discarded by Stevenson and Wolfers we are left with only India, a country that appears here solely in the analysis of life satisfaction, and whose exclusion would not alter the results. The basic data for all thirteen countries studied here and the rationale for the data chosen are given in Appendix B. We do not show there the results of an additional test that we ran - an estimate of the SWB mean at each 
date after controlling to the extent possible for shifts in population composition by gender, age, education, and size of place of residence. This analysis yielded patterns of change much like those in the data selected.

For countries for which we use two surveys to establish the trend in SWB, we compute the ordinary least squares (OLS) time trend for each series separately, and then a pooled regression that includes a dummy variable for one of the series. Because the wording of the SWB question and/or response categories change from one series to another, the dummy variable tells one whether the change has a significant effect on the level of the series. The detailed regression results for each country are given in Appendix B.

\section{Results}

Trends in subjective well-being. Within a country, life satisfaction and financial satisfaction almost always trend in the same direction, providing mutually consistent evidence of the longer-term movement in subjective well-being. In nine of the twelve countries for which the two measures are available, they both move upward, and in two, downward (compare the upper right and lower left quadrants of Figure 1). Peru is a borderline exception.

Life satisfaction is often seen as the net outcome of satisfaction with various domains of life - finances, family, health, work, friends, and so on (Easterlin and Sawangfa 2007; Saris, Veenhoven, Scherpenzeel, and Bunting 1995; Van Praag and Ferrer-i-Carbonell 2004). The significant relation between financial and life satisfaction found here provides new evidence consistent with the view that satisfaction with economic conditions is an important determinant of the time series movement in life satisfaction (cf. Easterlin and Plagnol 2008). This

relationship holds in Figure 1 despite the fact that the number of years spanned by the financial 
satisfaction series is sometimes different from that for life satisfaction. In four countries the difference is about one year, but in one (South Africa) it is around 9 years (see col. 2 of Tables 1 and 2).

In most countries the rates of change in subjective well-being are not very great, and, in all but Mexico and Venezuela, not significantly different from zero (Tables 1 and 2, column 4; the Japan 4 series, available for both life and financial satisfaction, is used in the Figure 1 analysis). It is noteworthy, however, that in nine of twelve countries, the regression coefficients for both life and financial satisfaction are positive, signifying some improvement over time, if not enough to achieve statistical significance. Possibly the lack of significance for six of the twelve countries is partly because the number of observations is only 3 to 5 . If, however, we regress log GDP instead of SWB on time, using only the dates for which there are SWB values, the trend coefficient is significant at the 5-percent level or better for three of the same six countries despite the few observations. Moreover, the issue of significance, or lack thereof, does not affect the findings on the two main questions below with which this chapter is primarily concerned.

The principal issue is whether countries with better economic performance exhibit more positive trends in SWB. To answer this, we turn to two specific questions:

(1) Do the actual trends in SWB conform to what might be expected based on the cross sectional relation of SWB and GDP per capita?

(2) Are the trends in SWB positively associated with the rate of economic growth?

Predicted and actual trends in SWB. The predicted trends in SWB are estimated here by the practice common in the literature of using a point-of-time comparison between richer and poorer countries to infer the likely course of happiness as GDP per capita rises (Frey and Stutzer 
2002; Layard 2005; Stevenson and Wolfers 2008). We then compare the actual trends in SWB in our thirteen countries with the predicted trends to see to what extent the international cross sectional relation of SWB to GDP per capita predicts the observed trends. Our finding is that the actual trends are not significantly related to the predicted trends. Put more strongly: knowing the actual change over time in a country's GDP per capita and the multi-country cross sectional relation of SWB to GDP per capita adds nothing, on average, to one's ability to predict the actual time series change in SWB in a country.

Our procedure in general is as follows. We first estimate the cross sectional relation between SWB and log GDP per capita by pooling all of the observations from all countries included in waves 1-4 of the WVS (the regression equations are reported in the source notes to Figures 2 and 3). We then estimate from the regression equations the predicted change in SWB by entering the change in log GDP per capita between the initial and terminal dates of observation for each country. Finally, we compare the predicted change in SWB with the actual change between these dates as estimated from a regression on time of the observed values of SWB.

The cross sectional relation of both life and financial satisfaction to absolute GDP per capita exhibits the typical pattern of diminishing marginal utility of income (Figures 2 and 3). A $\$ 5,000$ increment of GDP per capita from an initial level of $\$ 2,500$, for example, raises life satisfaction by almost 0.3 points on a 1-4 scale; in contrast, from an initial level of $\$ 17,500$, the increment in life satisfaction for the same absolute change in GDP per capita is less than onefourth as much, 0.07 points (Figure 2). The increments in financial satisfaction for corresponding changes in GDP per capita are respectively 0.33 and 0.08 on a 1-5 scale (Figure 3). Thus, the cross sectional regressions in Figures 2 and 3 demonstrate the assertion commonly 
made that a given absolute increase in GDP per capita has a greater impact on SWB in a poor than a rich country.

The calculation of the time series changes in life satisfaction predicted by the WVS cross section of Figure 2 can be illustrated by comparing the prediction for China, which comes close to the poorer country's situation in Figure 2, with that for Japan 1992-2007 (the Japan 3 segment), which illustrates the richer country's situation. In the period under study China's absolute growth in GDP per capita is $\$ 4,631$; Japan's, not much different, $\$ 4,409$ (Table 3, col. 4). But China's mean GDP per capita is about one fifth of Japan's -- $\$ 5,047$ compared with $\$ 26,372$ (column 2). Consequently, the slope of the regression curve, which indicates the increment in life satisfaction associated with a given increment in the dollar amount of GDP per capita, is considerably greater at China's GDP level than Japan's (column 3). To calculate the change in life satisfaction that one would predict for China based on the observed change in GDP per capita, we express China's GDP per capita at the beginning and end of the period in log terms, compute the difference (0.992; column 5) and multiply it by the slope coefficient $(0.270)$ of the cross sectional regression equation underlying Figure 2 (given in the source note for Figure 2). The result is a predicted change in China's life satisfaction of 0.268 for its GDP change of $\$ 4,631$. The same procedure for Japan yields a predicted change of 0.045 - about onesixth of that for China - for its GDP change of $\$ 4,409$.

The actual change in life satisfaction for each country is estimated from a regression on time of the life satisfaction values actually observed. For China, the slope coefficient of the regression, the change per year in life satisfaction is -0.0016 on a $1-4$ scale (Table 1 , column 4 ). Multiplying this by the number of years in the period under study, 12, yields the actual change in life satisfaction, -0.019 , as estimated from the time trend. For Japan, the slope coefficient of 
observed life satisfaction on time is -0.0122 ; the period, 15 years; and the estimated actual change in life satisfaction, -0.183 . Thus we obtain for China a predicted change in life satisfaction from the WVS cross section of 0.268 , and an actual change, based on the observed life satisfaction time trend, of -0.019. For Japan, the corresponding values are: predicted, 0.045; actual, -0.183 (these are the values for China and Japan that appear in columns 6 and 7 of Table 3).

For life satisfaction there are 13 other cases - yielding a total of 15 altogether - for which we can estimate the actual change in life satisfaction and compare it with that predicted from the WVS cross section. These fifteen paired observations (listed in columns 6 and 7 of Table 3) are plotted in Figure 4. If the actual changes corresponded to those predicted from the cross sectional relationship, the 15 observations would fall along the positively sloped dotted line in Figure 4, a line with a slope of 1.0. For 9 of the 15 life satisfaction observations the actual change is less than the predicted change (the points falling below the dotted line), and in four of these cases (China, Chile, India, Japan 3) the actual change is negative while the predicted change is positive. Six countries (Venezuela, Mexico, Turkey, Argentina, Nigeria, and South Africa) have changes in life satisfaction considerably in excess of what one would expect based on the cross sectional relation. For financial satisfaction the distribution of countries above and below the dotted line is quite similar to that for life satisfaction, except that Brazil shifts from slightly below to slightly above the dotted line (Figure 5).

A regression line fitted to the 15 observations in Figure 4 - the solid line plotted in the figure - actually has a somewhat negative slope, -0.152 , though it is not statistically significant (the regression statistics are reported in Table 5). Moreover, the dotted line slope coefficient of 1.0 lies outside a two-standard-error range of the solid line slope coefficient of -0.152 . The same 
conclusions hold for the coefficients in the analysis of financial satisfaction in Figure 5. We conclude, therefore, that for the thirteen countries studied here the actual changes in SWB typically have no relation to the cross sectional pattern. The practice common in the literature, to infer time trends in SWB from the cross sectional relationship of SWB to GDP per capita, finds no support in this analysis.

Japan is of special interest, because it traverses such a broad range of GDP per capita. Compared to the United States GDP per capita level in 2000, Japan moved from 11 percent in 1958 to about 80 percent in 2006. Based on the international cross sectional pattern in Figure 2 this impressive growth in GDP per capita should have raised life satisfaction by 0.52 points, about one-sixth of the way along a 1-4 scale. The actual change in life satisfaction over this 48year period, as estimated from a regression of life satisfaction on time, is slightly (but not significantly) positive, 0.06 points. (The regression is given in Appendix B.)

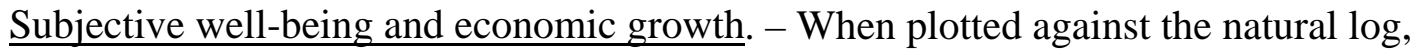
rather than the absolute value of GDP per capita, the cross sectional regressions underlying Figures 2 and 3 above imply that higher rates of economic growth are accompanied by greater improvements in SWB. In the Figure 6 cross section, for example, where GDP is now on a logarithmic scale, an increase in GDP per capita from $\$ 1,000$ to $\$ 2,000$ (an increase in log GDP per capita from 6.91 to 7.60 ) raises life satisfaction by 0.18 points. Doubling the rate of economic growth, i.e. raising GDP per capita from $\$ 1,000$ to $\$ 4,000$ (log GDP per capita, from 6.91 to 8.29 ) doubles the increase in life satisfaction to 0.36 points. Figure 7 indicates for financial satisfaction a similar relationship, a doubling of the rate of economic growth accompanied by a doubling of the rate of subjective well-being. 
The relationship that one would predict from the cross sectional regression between the rate of change per year in GDP per capita (in percentage terms) and that in SWB (in absolute amounts) is shown by the dotted lines marked "Predicted Relation" in Figures 8 and 9. The points in these lines are obtained by using the regression equations given at the bottom of Figures 2 and 3 to estimate the improvement in SWB that would result from annual growth rates of GDP per capita of 1, 3, 5 percent, and so on. The dotted lines demonstrate that higher growth rates of SWB are expected to be associated with higher rates of economic growth.

Is a higher growth rate of GDP per capita in fact accompanied by a higher growth rate of SWB? To assess this, we plot in Figures 8 and 9 the values for each country of the actual rates of change per year in SWB and GDP per capita (given in columns 4 and 5 of Tables 1 and 2). Without exception, countries with quite high rates of growth in GDP per capita, 4 percent per year or more, fall below the dotted line, indicating that the improvement in SWB is less than what one would expect based on the cross section. In contrast, countries with growth rates of GDP per capita lower than 4 percent fall on either side of the dotted line - some have a greater improvement in SWB than would be predicted from the cross section; others less. Regression lines fitted to the country data on growth rates of SWB and GDP per capita - the solid lines in Figures 8 and 9 marked “Actual Relation" - are, in fact, negatively, not positively inclined. For one of them, financial satisfaction, the slope coefficient is statistically significant at the 10percent level (Table 6). In both figures the dotted line ("Predicted Relation") slope coefficient lies outside a two-standard-error range of the solid line (“Actual Relation”) slope coefficient. A conservative conclusion would seem to be that for the thirteen developing countries studied here there is no evidence that more rapid economic growth is accompanied by a greater improvement in happiness. 


\section{Conclusion}

The experience of thirteen developing countries, scattered across three continents, fails to show any consistent relation between long-term economic growth and the growth rate of subjective well-being. This is true for two measures of subjective well-being that were separately analyzed, life satisfaction and financial satisfaction. The absence of any relationship between financial satisfaction and GDP per capita is especially noteworthy, because this is the SWB measure that one would expect to be most strongly affected by economic growth. However, the two measures of subjective well-being themselves typically trend similarly within a country, providing mutually supporting evidence of the movement in subjective well-being.

Point-of-time cross sectional regressions of SWB on GDP per capita are often used as a basis for inferring that economic growth raises subjective well-being, especially in poorer countries. For the developing countries studied here there is no relation between expectations based on cross sectional data and actual time series experience - one more bit of evidence that cross sectional relationships are a questionable basis for inferring change over time (cf. Easterly 1999). Of course, we are examining here only the simple bivariate relation between the growth rates of SWB and GDP per capita, but it is the bivariate relation between SWB and GDP per capita that has provided the cross sectional evidence underlying generalizations that economic growth would raise subjective well-being.

Our conclusions are subject to a number of qualifications. We consider only thirteen of the world's developing countries, though a number of them are the most populous in the world and several have quite high rates of economic growth. Our time series for subjective well-being are short, averaging 16 years. We have tried to minimize shorter-term disturbances by computing growth rates over the full time span covered by the data for each country, but we 
cannot rule out the possibility that shorter-term influences still affect our estimates of the longterm trend. To maximize the time span covered, we use for some countries data from two different sources. We have tried to screen and test all of the data for comparability over time, but there is no assurance that our procedures are foolproof.

Despite our efforts, one can undoubtedly find reason to fault the SWB data. But for those so inclined, it is perhaps worth pointing out the consistency in the present results. Consider, for example, three countries with very high recent growth rates of GDP per capita -- China, Chile, and South Korea. China's growth rate implies a doubling of real income in less than 10 years; South Korea's, in 13 years; and Chile's in 18 years. With the per capita amount of goods multiplying so rapidly in a fraction of a lifetime, one might think many of the people in these countries would be so happy they'd be dancing in the streets. Yet both China and Chile show mild (not statistically significant) declines in SWB - China in surveys conducted by three separate statistical organizations. South Korea - none of whose surveys has been faulted shows a (not statistically significant) increase, but all of the increase results from the low value reported in the 1980 survey, one that was conducted a few months after the assassination of the country's president. Thereafter, in four surveys from 1990 to 2005, a period when GDP per capita continued to grow rapidly, averaging 5 percent per year, subjective well-being is constant or declining slightly. With incomes increasing so greatly in three different countries it is surprising, to say the least, that there are no surveys that register the marked improvement in subjective well-being that one might expect based on the cross sectional relationship.

We do find that countries that have higher growth rates of satisfaction with finances typically have higher growth rates of overall life satisfaction. One might reasonably ask, therefore, if financial satisfaction is closely linked to life satisfaction, as this result indicates, why 
doesn't subjective well-being improve with economic growth? One possible answer to this question is that there are offsetting changes in other happiness domains such as family life. Another, which has some support in the growing body of happiness research, is that while economic growth raises objective living conditions, it also raises the standards by which people judge their living conditions (cf., e.g., Clark, Frijters, and Shields 2008). There is nothing to suggest that those in developing countries are immune to this rise in material aspirations, and that this aspiration mechanism operates only beyond some unspecified "basic needs" point. This rise in standards would undercut the positive impact on well-being of objectively improved living conditions, as measured by GDP per capita. As a result, perceptions of one's financial situation, which is what the survey questions here capture, do not rise commensurately with the objective improvement in living conditions.

Clearly, the results here point to the need for deeper research into the happiness-growth relationship - to the need for consideration of the various effects of economic growth - not only via the accumulation of material goods, but also through aspirations, and work, health, and family concerns. They suggest too the urgency of time series study to test the current plethora of SWB generalizations based only on point-of-time cross sections. 


\section{Acknowledgements}

All those who have used the WVS data must be grateful for this impressive survey undertaking by Ronald Inglehart and his collaborators that has placed in the public domain information on subjective attitudes and well-being for so many countries throughout the world over the past two to three decades. Without these data the present study would not have been possible.

We have benefited from suggestions made by Timothy Biblarz, Ed Diener, John Ham, John Helliwell, Betsey Stevenson and Justin Wolfers, and the generous assistance of Jacqueline Smith and Laura Angelescu. For their help in providing data and comments thereon, special thanks are due to Valerie Møller (South Africa) and Takayoshi Kusago (Japan). Financial support was provided by the University of Southern California. 
Table 1: Annual Growth Rates of Life Satisfaction and GDP per Capita in Specified Country during Specified Period (countries arrayed from high to low by growth rate of GDP per capita)

(1)

\begin{tabular}{|c|c|c|c|c|c|}
\hline \multirow[b]{2}{*}{ Country } & \multirow[b]{2}{*}{ Period } & \multirow[b]{2}{*}{ Years } & \multicolumn{2}{|c|}{ Life satisfaction } & \multirow{2}{*}{$\begin{array}{l}\text { GDP per capita } \\
\text { \% change per } \\
\text { year (PPP } 2000 \\
\text { international } \\
\text { dollars) }\end{array}$} \\
\hline & & & $\begin{array}{c}\text { Number of } \\
\text { observations }\end{array}$ & $\begin{array}{l}\text { Change per } \\
\text { year } * 10^{-2} \\
(1-4) \text { scale }\end{array}$ & \\
\hline Japan 1 & $1958-1969$ & 11 & 12 & $1.37^{*}$ & 9.40 \\
\hline China & $1995-2007$ & 12 & 3 & -0.16 & 8.61 \\
\hline South Korea & $1980-2005$ & 25 & 4 & 1.04 & 5.40 \\
\hline India & $1995-2006$ & 11 & 3 & -0.28 & 4.95 \\
\hline Chile & $1989.5-2006$ & 16.5 & 7 & -0.94 & 4.04 \\
\hline Japan 2 & 1970-1991 & 21 & 25 & $0.56 * *$ & 3.29 \\
\hline Turkey & $1990-2007$ & 17 & 4 & 1.60 & 2.33 \\
\hline Peru & $1995.5-2006$ & 10.5 & 7 & 0.15 & 2.18 \\
\hline Mexico & $1989.5-2006$ & 16.5 & 8 & $2.10 *$ & 1.63 \\
\hline Brazil & 1991-2006 & 15 & 7 & 0.22 & 1.28 \\
\hline Argentina & 1984-2006 & 22 & 8 & 1.13 & 1.15 \\
\hline Japan 3 & 1992-2007 & 15 & 14 & $-1.22 * *$ & 1.12 \\
\hline Venezuela & 1995-2006 & 11 & 7 & $3.90 *$ & 0.53 \\
\hline Nigeria & $1989.5-2000$ & 10.5 & 3 & 1.80 & 0.19 \\
\hline $\begin{array}{l}\text { South Africa } \\
\text { Addendum }\end{array}$ & \multicolumn{5}{|c|}{ Addendum } \\
\hline$\overline{\text { Japan }}$ & $1958-2007$ & 49 & 51 & 0.13 & 4.03 \\
\hline Japan 4 & $1981-2005$ & 24 & 5 & 0.42 & 1.97 \\
\hline+ significant & $\%$; * significa & t 5\% & ${ }^{*}$ significant a & $1 \%$ & \\
\hline
\end{tabular}


Table 2: Annual Growth Rates of Financial Satisfaction and GDP per Capita in Specified Country during Specified Period (countries arrayed from high to low by growth rate of GDP per capita)

(1)

(2)

(3)

(4)

(5)

\begin{tabular}{|c|c|c|c|c|c|}
\hline \multirow[b]{2}{*}{ Country } & \multirow[b]{2}{*}{ Period } & \multirow[b]{2}{*}{ Years } & \multicolumn{2}{|c|}{ Financial satisfaction } & \multirow{2}{*}{$\begin{array}{l}\text { GDP per } \\
\text { capita } \\
\text { \% change per } \\
\text { year (PPP 2000 } \\
\text { international } \\
\text { dollars) }\end{array}$} \\
\hline & & & $\begin{array}{c}\text { Number of } \\
\text { observations }\end{array}$ & $\begin{array}{l}\text { Change per } \\
\text { year } * 10^{-2} \\
(1-5) \text { scale }\end{array}$ & \\
\hline China & $1995-2007$ & 12 & 3 & -0.58 & 8.61 \\
\hline South Korea & $1980-2005$ & 25 & 5 & 0.92 & 5.40 \\
\hline Chile & $1989.5-2005$ & 15.5 & 12 & -0.27 & 4.11 \\
\hline Turkey & $1990-2007$ & 17 & 4 & 1.47 & 2.33 \\
\hline Japan 4 & $1981-2005$ & 24 & 5 & 0.13 & 1.97 \\
\hline Peru & $1994.5-2005$ & 10.5 & 10 & -1.34 & 1.91 \\
\hline Mexico & $1989.5-2005$ & 15.5 & 12 & $4.91 *$ & 1.50 \\
\hline Brazil & $1991-2005$ & 14 & 12 & 0.93 & 1.19 \\
\hline South Africa & $1990-2007$ & 17 & 4 & 3.55 & 0.98 \\
\hline Argentina & $1984-2005$ & 21 & 13 & 0.65 & 0.86 \\
\hline Nigeria & $1989.5-2000$ & 10.5 & 3 & 4.53 & 0.19 \\
\hline Venezuela & $1994.5-2005$ & 10.5 & 10 & 1.98 & -0.14 \\
\hline
\end{tabular}

Source: See Table 1. 
Table 3: Full-Period Change in Life Satisfaction, Actual and That Predicted from Figure 2 Cross Section (Countries arrayed from low to high by mean GDP per capita in specified period)

\begin{tabular}{|c|c|c|c|c|c|c|c|}
\hline \multirow[b]{3}{*}{ Country } & \multirow[b]{3}{*}{ Period } & \multirow[b]{3}{*}{$\begin{array}{l}\text { Mean GDP } \\
\text { per capita } \\
\text { (PPP } 2000 \\
\text { international } \\
\text { dollars) }\end{array}$} & \multirow[b]{3}{*}{$\begin{array}{l}\text { Predicted } \\
\Delta \text { LS per } \\
\$ 1000 \\
\text { GDP per } \\
\text { capita }\end{array}$} & (4) & (5) & (6) & (7) \\
\hline & & & & \multicolumn{2}{|c|}{$\Delta$ GDP per capita } & \multirow[b]{2}{*}{$\begin{array}{l}\text { Predicted } \\
\Delta \text { LS, full } \\
\text { period }\end{array}$} & \multirow[b]{2}{*}{$\begin{array}{l}\text { Actual } \Delta \mathrm{LS} \text {, } \\
\text { full period }\end{array}$} \\
\hline & & & & $\begin{array}{l}\text { PPP } 2000 \\
\text { international } \\
\text { dollars }\end{array}$ & Natural log & & \\
\hline Nigeria & $1989.5-2000$ & 838.1 & 0.322 & 16.4 & 0.020 & 0.005 & 0.189 \\
\hline India & $1995-2006$ & $2,626.0$ & 0.105 & $1,363.8$ & 0.532 & 0.144 & -0.030 \\
\hline China & $1995-2007$ & $5,047.0$ & 0.058 & $4,631.1$ & 0.992 & 0.268 & -0.019 \\
\hline Peru & $1995.5-2006$ & $5,145.1$ & 0.053 & $1,160.0$ & 0.226 & 0.061 & 0.016 \\
\hline Venezuela & $1995-2006$ & $6,301.7$ & 0.043 & 367.2 & 0.058 & 0.016 & 0.429 \\
\hline Turkey & $1990-2007$ & $6,778.3$ & 0.040 & $2,623.7$ & 0.392 & 0.106 & 0.271 \\
\hline Brazil & 1991-2006 & $7,148.5$ & 0.038 & $1,354.5$ & 0.190 & 0.051 & 0.033 \\
\hline Japan 1 & $1958-1969$ & $7,591.5$ & 0.038 & $6,946.9$ & 0.988 & 0.267 & 0.151 \\
\hline Chile & $1989.5-2006$ & $8,314.9$ & 0.034 & $5,247.3$ & 0.653 & 0.177 & -0.154 \\
\hline Mexico & 1989.5-2006 & $8,800.6$ & 0.031 & $2,333.3$ & 0.267 & 0.072 & 0.346 \\
\hline South Africa & 1981-2007 & $10,562.4$ & 0.026 & 453.9 & 0.043 & 0.012 & 0.096 \\
\hline Argentina & 1984-2006 & $12,135.1$ & 0.022 & $3,034.6$ & 0.251 & 0.068 & 0.248 \\
\hline South Korea & 1980-2005 & $12,461.5$ & 0.025 & $14,364.1$ & 1.314 & 0.355 & 0.261 \\
\hline Japan 2 & 1970-1991 & $18,079.2$ & 0.016 & $11,830.5$ & 0.679 & 0.184 & 0.117 \\
\hline $\begin{array}{l}\text { Japan } 3 \\
\text { Addendum } \\
\end{array}$ & $1992-2007$ & $26,372.0$ & 0.010 & $4,408.9$ & 0.168 & 0.045 & -0.183 \\
\hline$\overline{\text { Japan }}$ & $1958-2007$ & $16,347.2$ & 0.021 & $24,458.4$ & 1.937 & 0.524 & 0.062 \\
\hline Japan 4 & $1981-2005$ & $22,222.8$ & 0.012 & $10,243.5$ & 0.469 & 0.127 & 0.100 \\
\hline
\end{tabular}


Table 4: Full-Period Change in Financial Satisfaction, Actual and That Predicted from Figure 3 Cross-section (Countries arrayed from low to high by mean GDP per capita in specified period)

(1)

(2)

(3)

(4)

$\Delta$ GDP per capita

$\Delta$ GDP per capita

\begin{tabular}{|c|c|c|c|c|c|c|c|}
\hline Country & Period & $\begin{array}{l}\text { Mean GDP } \\
\text { per capita } \\
\text { (PPP 2000 } \\
\text { international } \\
\text { dollars) }\end{array}$ & $\begin{array}{l}\text { Predicted } \\
\Delta \text { LS per } \\
\$ 1000 \\
\text { GDP per } \\
\text { capita }\end{array}$ & $\begin{array}{l}\text { PPP 2000 } \\
\text { international } \\
\text { dollars }\end{array}$ & Natural log & $\begin{array}{l}\text { Predicted } \\
\Delta \text { LS, full } \\
\text { period }\end{array}$ & $\begin{array}{l}\text { Actual } \Delta \mathrm{LS} \text {, } \\
\text { full period }\end{array}$ \\
\hline Nigeria & $1989.5-2000$ & 838.1 & 0.364 & 16.4 & 0.020 & 0.006 & 0.475 \\
\hline Peru & $1994.5-2005$ & $4,890.3$ & 0.063 & 970.0 & 0.199 & 0.061 & -0.141 \\
\hline China & 1995-2007 & $5,047.0$ & 0.065 & $4,631.1$ & 0.992 & 0.303 & -0.070 \\
\hline Venezuela & $1994.5-2005$ & $6,020.4$ & 0.051 & -88.5 & -0.015 & -0.004 & 0.208 \\
\hline Turkey & 1990-2007 & $6,778.3$ & 0.046 & $2,623.7$ & 0.392 & 0.120 & 0.250 \\
\hline Brazil & 1991-2005 & $7,055.1$ & 0.043 & $1,167.8$ & 0.166 & 0.051 & 0.130 \\
\hline Chile & $1989.5-2005$ & $8,156.9$ & 0.039 & $4,931.2$ & 0.624 & 0.190 & -0.042 \\
\hline Mexico & $1989.5-2005$ & $8,625.9$ & 0.036 & $1,983.9$ & 0.231 & 0.071 & 0.762 \\
\hline South Africa & $1990-2007$ & $9,968.3$ & 0.031 & $1,642.2$ & 0.165 & 0.050 & 0.604 \\
\hline Argentina & 1984-2005 & $11,663.5$ & 0.026 & $2,091.5$ & 0.180 & 0.055 & 0.137 \\
\hline South Korea & $1980-2005$ & $12,461.5$ & 0.028 & $14,364.1$ & 1.314 & 0.401 & 0.231 \\
\hline Japan 4 & $1981-2005$ & $22,222.8$ & 0.014 & $10,243.5$ & 0.469 & 0.143 & 0.032 \\
\hline
\end{tabular}


Table 5: Regression Relationships between Full-Period Actual Change in Subjective Well-Being and Change Predicted from WVS Cross-Section

\begin{tabular}{lcc} 
& \multicolumn{2}{c}{ Actual Change } \\
\cline { 2 - 3 } & $\begin{array}{c}\text { Life } \\
\text { satisfaction }\end{array}$ & $\begin{array}{c}\text { Financial } \\
\text { satisfaction }\end{array}$ \\
\hline Predicted change & -0.15191 & -0.72643 \\
& {$[0.744]$} & {$[0.305]$} \\
Constant & 0.13662 & 0.30221 \\
Observations & {$[0.084]+$} & {$[0.024]^{*}$} \\
R-squared & 15 & 12 \\
\hline p values in brackets & 0.008 & 0.104 \\
+ significant at 10\%; * & significant at 5\%; \\
** significant at 1\% & & \\
\hline
\end{tabular}

Source: Life satisfaction, Table 3, cols. 6 and 7; financial satisfaction, Table 4, cols. 6 and 7 . For each country the change in SWB is measured over the full period spanned by the SWB data.

Table 6: Regression Relationships between Annual Growth Rates of Subjective Well-Being and GDP per capita

(1)

(2)

\begin{tabular}{lll}
\hline & $\begin{array}{c}\Delta \text { Life } \\
\text { satisfaction }\end{array}$ & $\begin{array}{l}\boldsymbol{\Delta} \text { Financial } \\
\text { satisfaction }\end{array}$ \\
\hline $\boldsymbol{\Delta}$ GDP per capita & -0.10084 & -0.4007 \\
& {$[0.419]$} & {$[0.096]+$} \\
Constant & 1.08787 & 2.37295 \\
& {$[0.050]^{*}$} & {$[0.010]^{* *}$} \\
Observations & 15 & 12 \\
R-squared & 0.051 & 0.252 \\
\hline p values in brackets & \\
+ significant at 10\%; & significant at 5\%; \\
** significant at 1\% & \\
\hline
\end{tabular}

Source: Col. 1 from Table 1, cols. 4 and 5; col. 2 from Table 2, cols. 4 and 5. Growth rates of SWB are in absolute amount per year; of GDP per capita, percent per year. 
Figure 1: Annual Rate of Change in Life Satisfaction and Financial Satisfaction

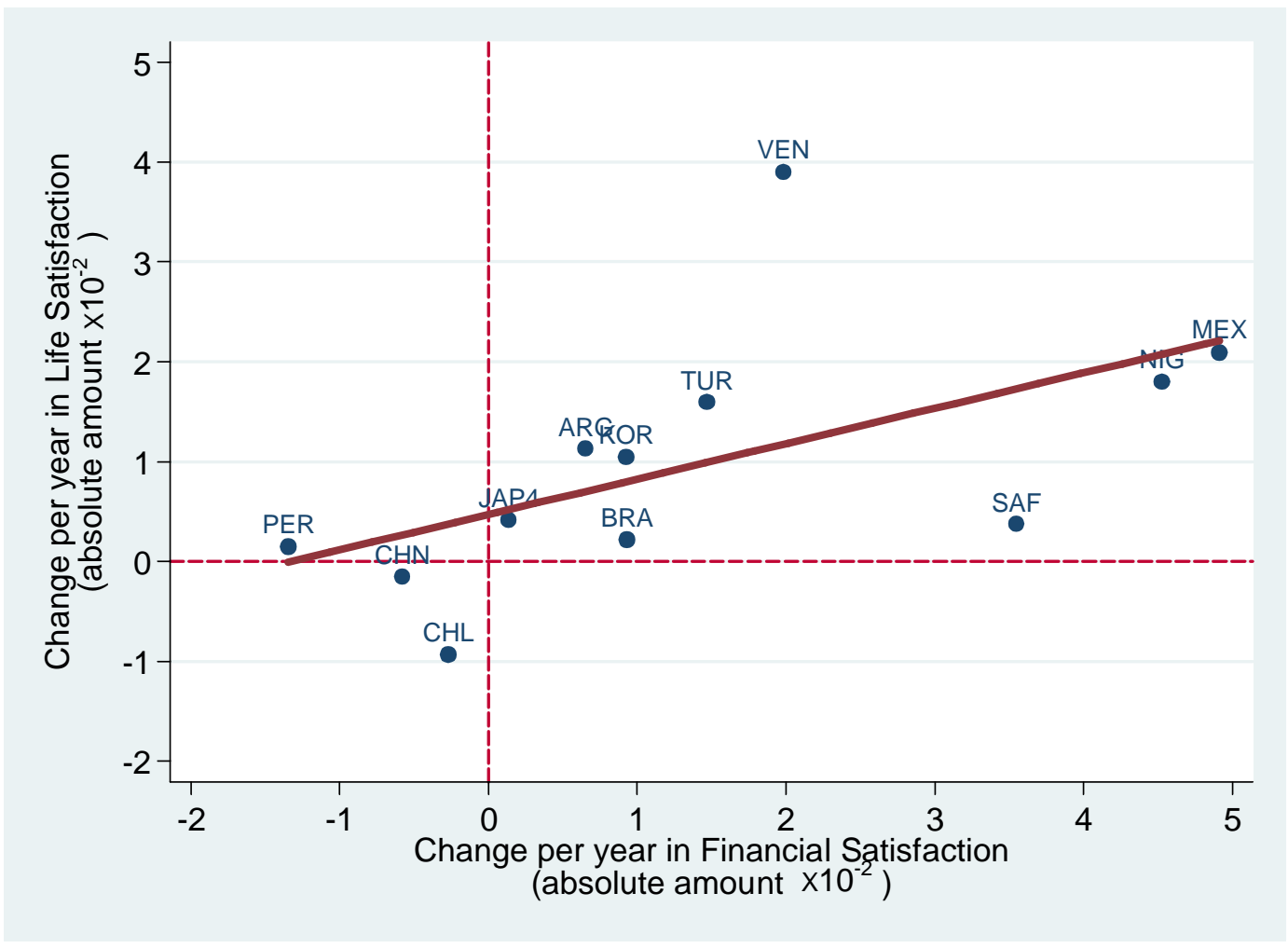

Source: Column 4 of Tables 1 and 2. The fitted OLS regression is $y=0.47081+0.35442 x$; $\mathrm{n}=12$; adjusted $\mathrm{R}^{2}=0.24$; $\mathrm{t}$-statistics in parentheses.

(1.19) (2.12) 
Figure 2: Regression of Life Satisfaction on GDP per capita, WVS Cross Section (GDP per capita on absolute scale; 195 observations for 89 countries)

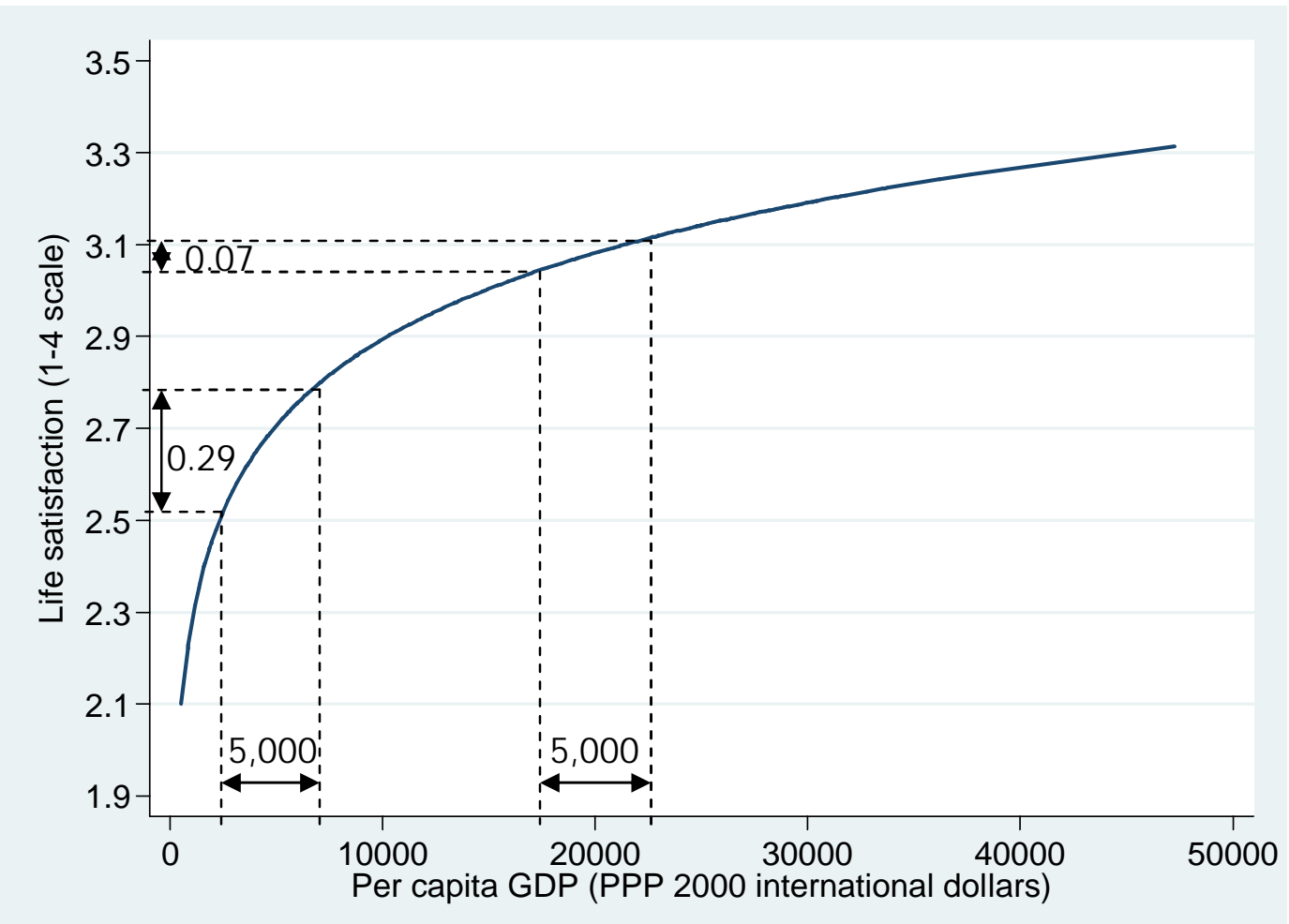

Source: WVS, Waves 1-4. The fitted regression is $\mathrm{y}=0.405+0.270 \ln (\mathrm{x})\left(\mathrm{n}=195\right.$, adjusted $\left.\mathrm{R}^{2}=0.452\right)$; t-statistics in parentheses (2.05) (12.68) 
Figure 3: Regression of Financial Satisfaction on GDP per capita, WVS Cross Section (GDP per capita on absolute scale; 136 observations for 54 countries)

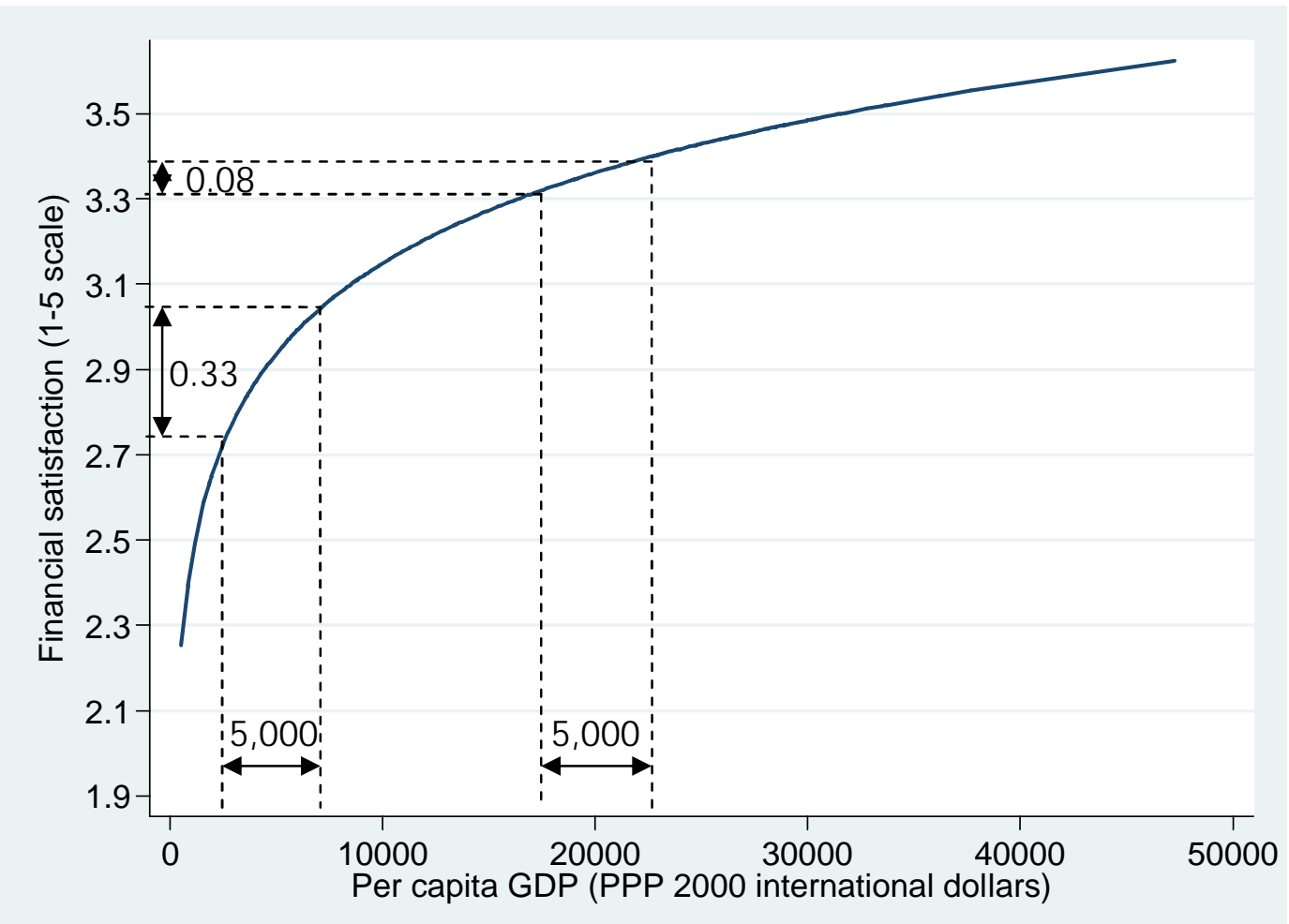

Source: WVS, Waves 1-4. The fitted regression is $y=0.338+0.305 \ln (\mathrm{x})\left(\mathrm{n}=136\right.$, adjusted $\left.\mathrm{R}^{2}=0.31\right)$; $\mathrm{t}$-statistics in parentheses.

$$
\text { (0.96) (7.85) }
$$


Figure 4: Actual Change in Life Satisfaction and That Predicted from Change in GDP per capita Using WVS Cross Sectional Regression in Figure 2

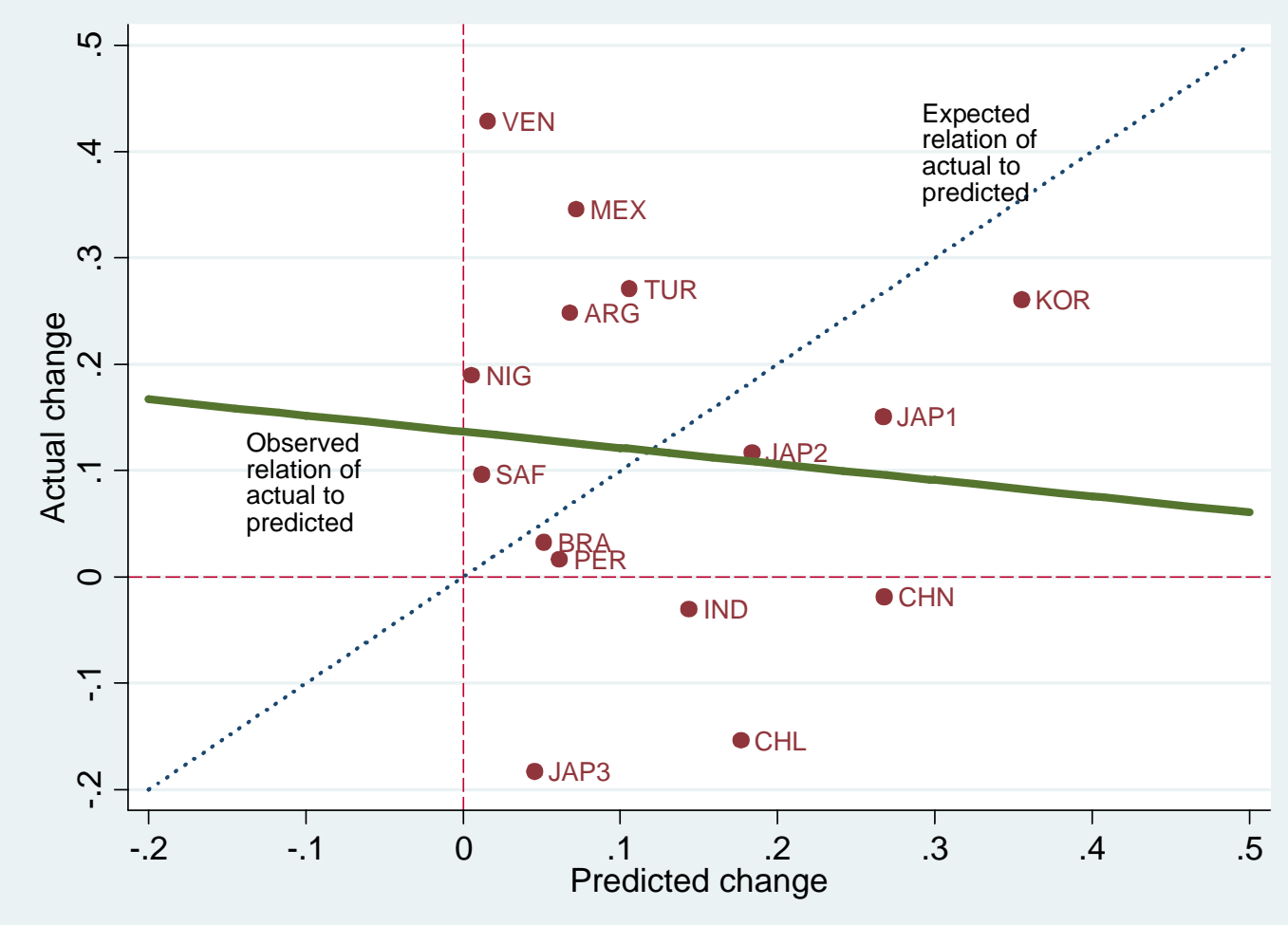

Source: Table 3, columns 6 and 7; regression statistics, Table 5. For each country the change in life satisfaction is measured over the full period spanned by the life satisfaction data. 
Figure 5: Actual Change in Financial Satisfaction and That Predicted from Change in GDP per capita Using WVS Cross Sectional Regression in Figure 3

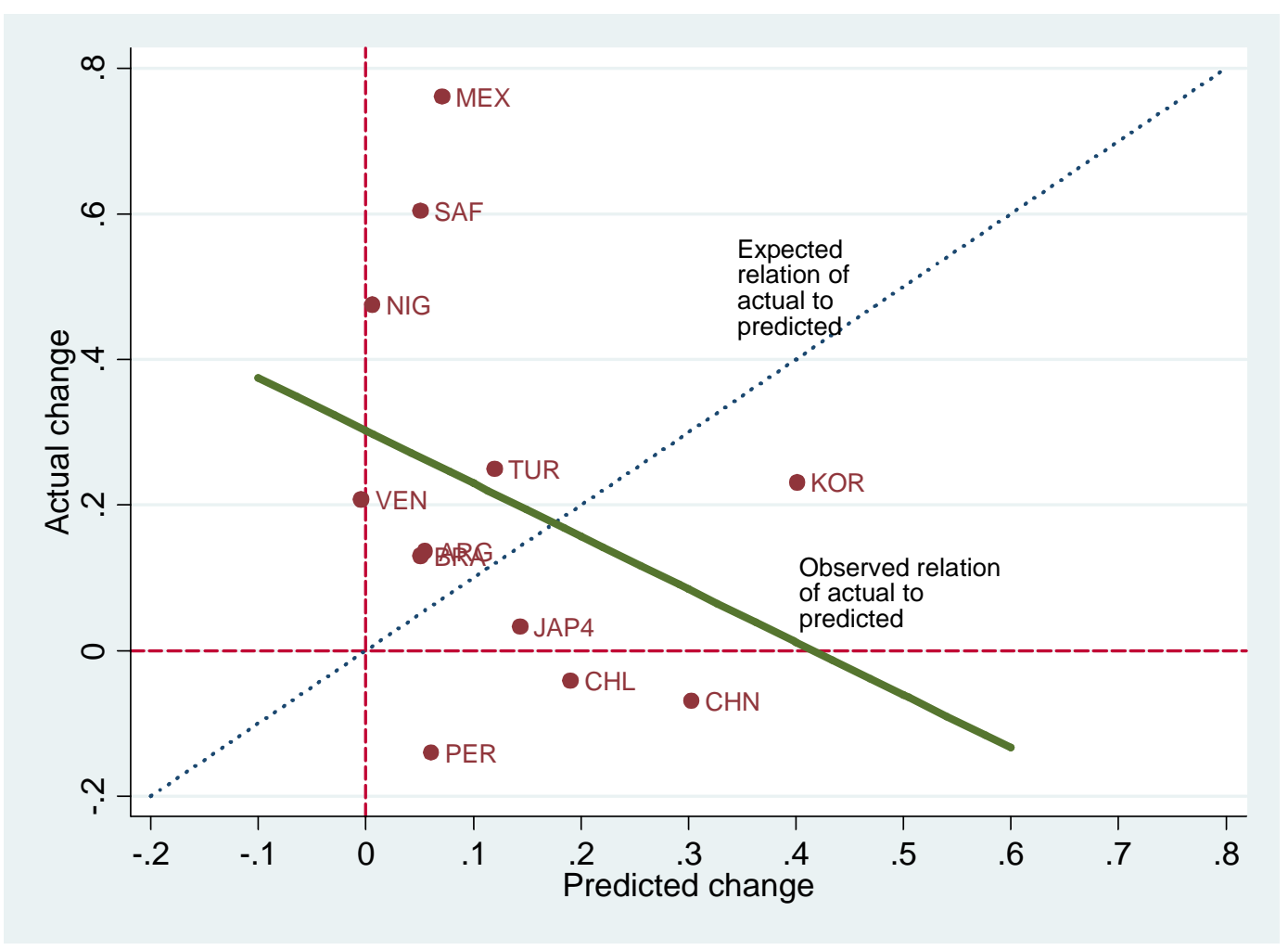

Source: Table 4, columns 6 and 7; regression statistics, Table 5. For each country the change in financial satisfaction is measured over the full period spanned by the financial satisfaction data. 
Figure 6: Life Satisfaction and GDP per capita, WVS Cross-section (GDP per capita on logarithmic scale)

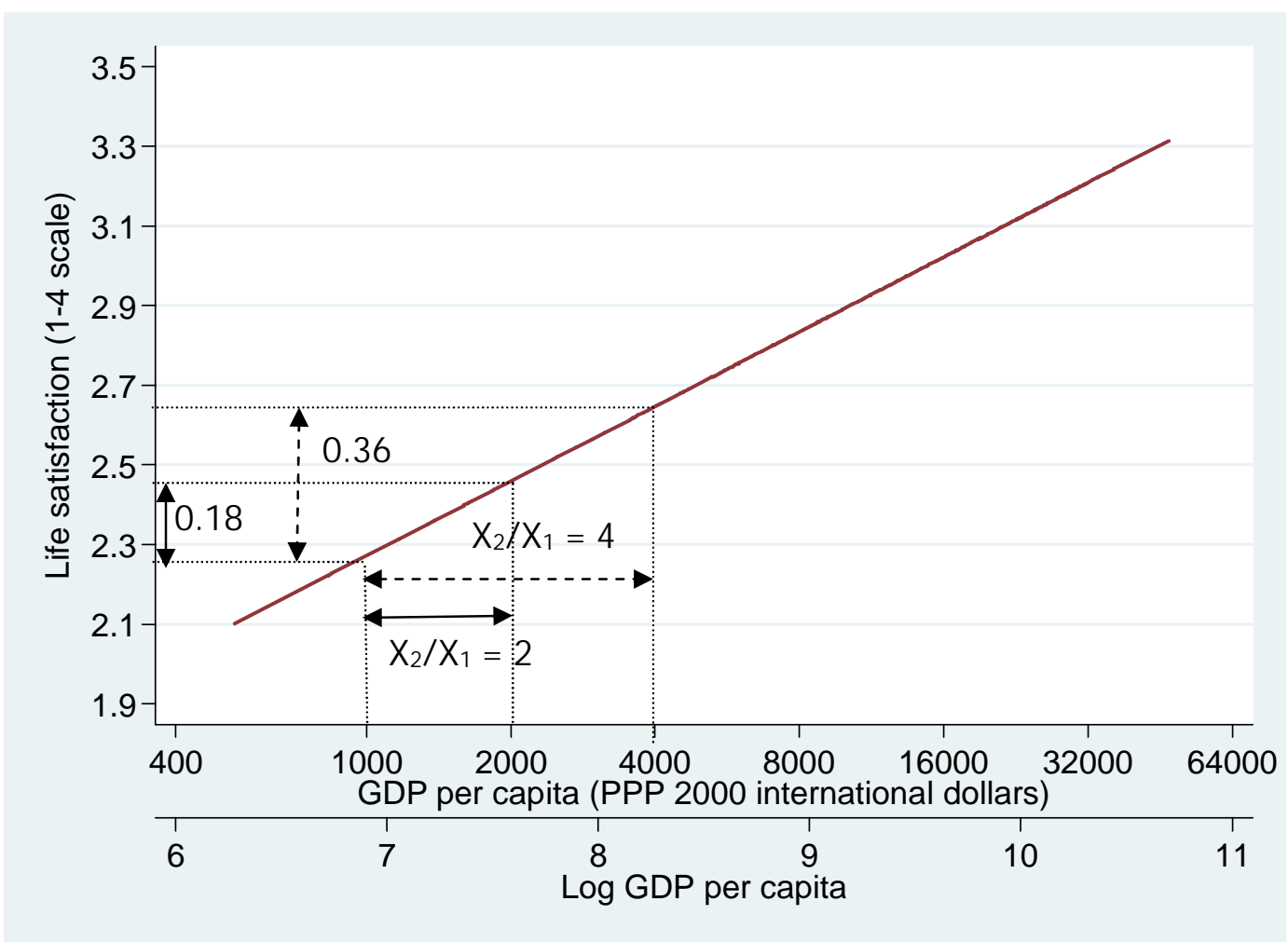

Source: The regression equation is the same as that for Figure 2. 
Figure 7: Financial Satisfaction and GDP per capita, WVS Cross-section (GDP per capita on logarithmic scale)

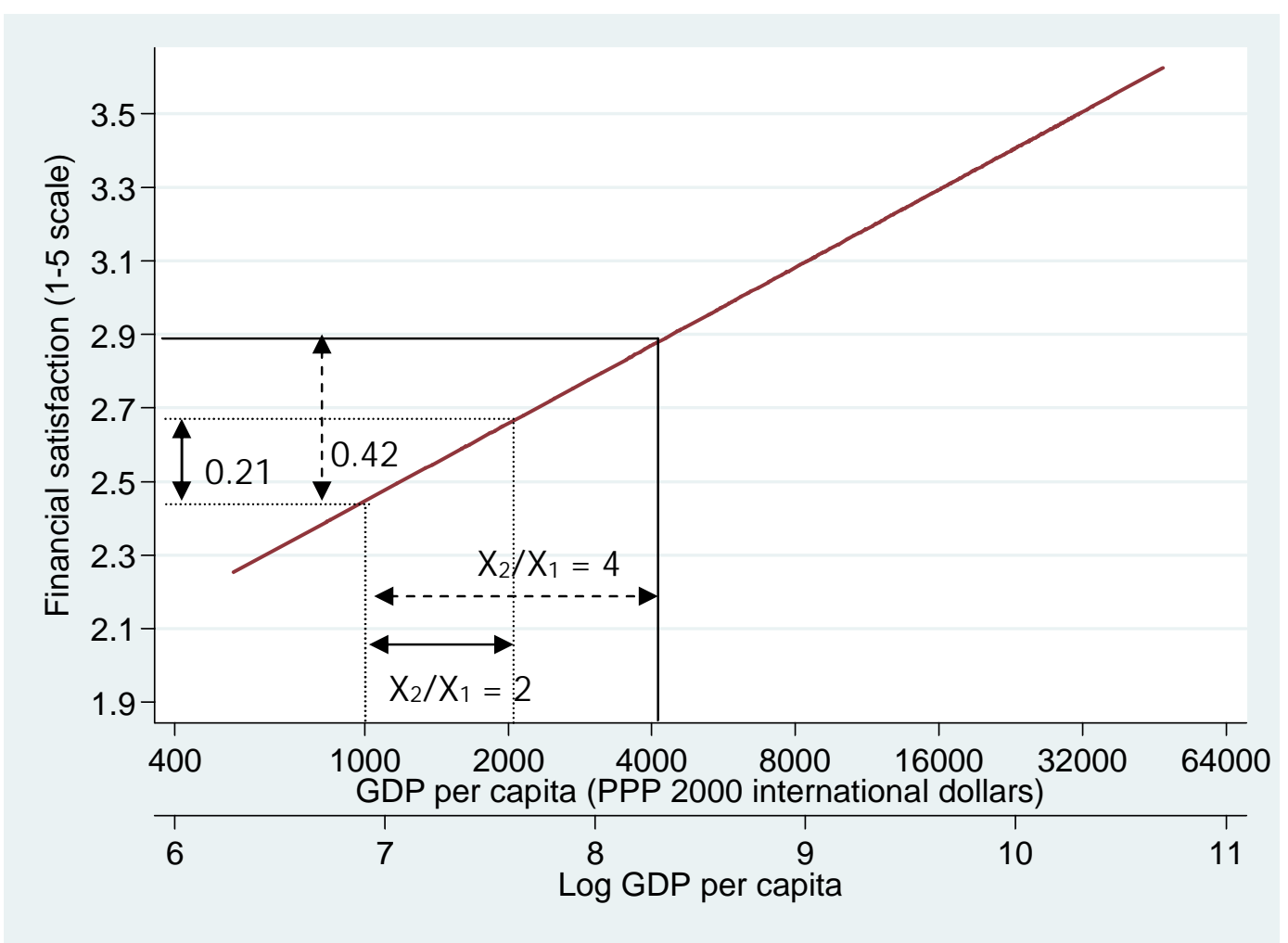

Source: The regression equation is the same as that for Figure 3. 
Figure 8: Annual Rate of Change in Life Satisfaction and in GDP per capita, Actual and That Predicted from WVS Cross Section

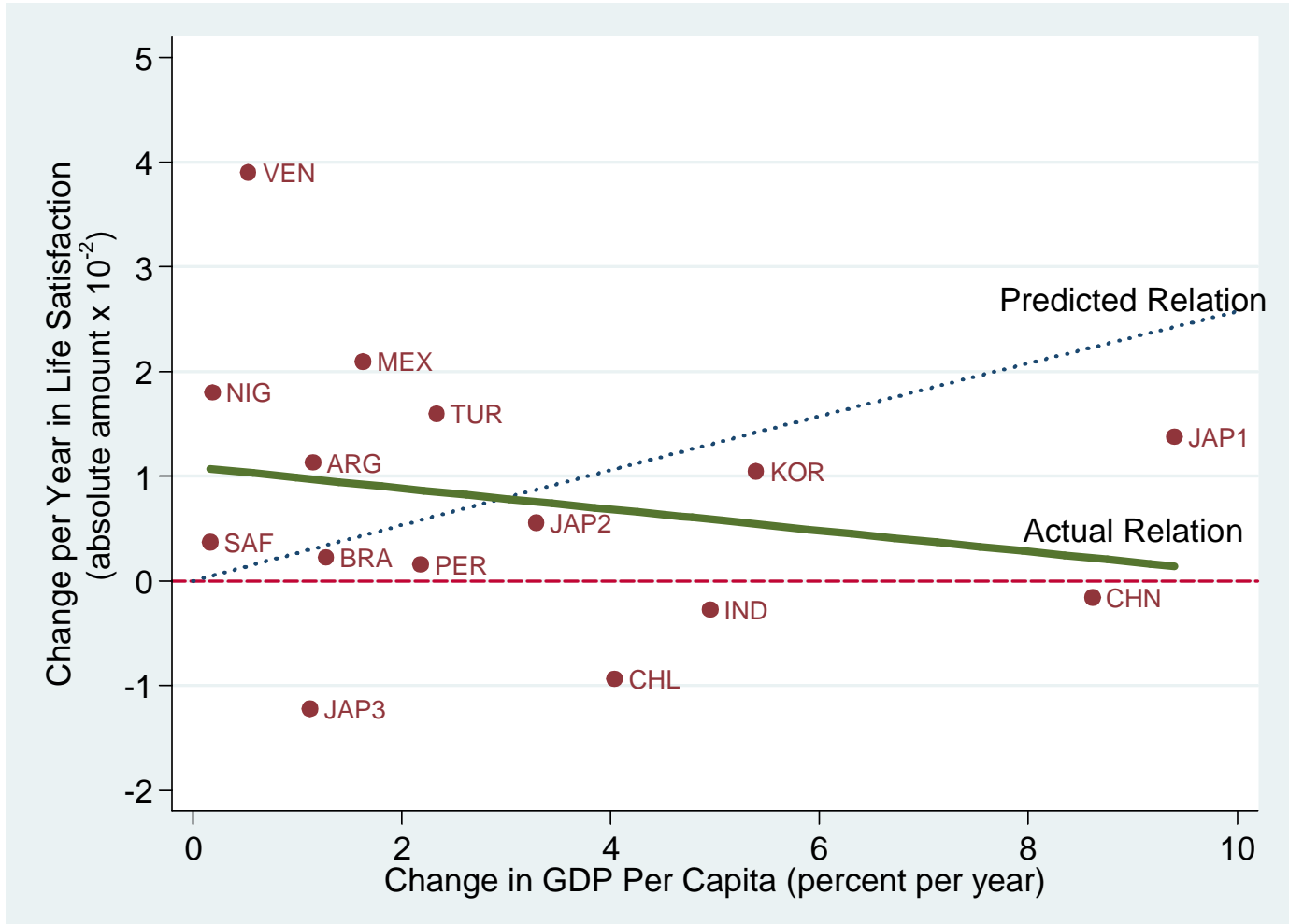

Source: Table 1, cols. 4 and 5; regression statistics, Table 6. 
Figure 9: Annual Rate of Change in Financial Satisfaction and in GDP per capita, Actual and That Predicted from WVS Cross Section

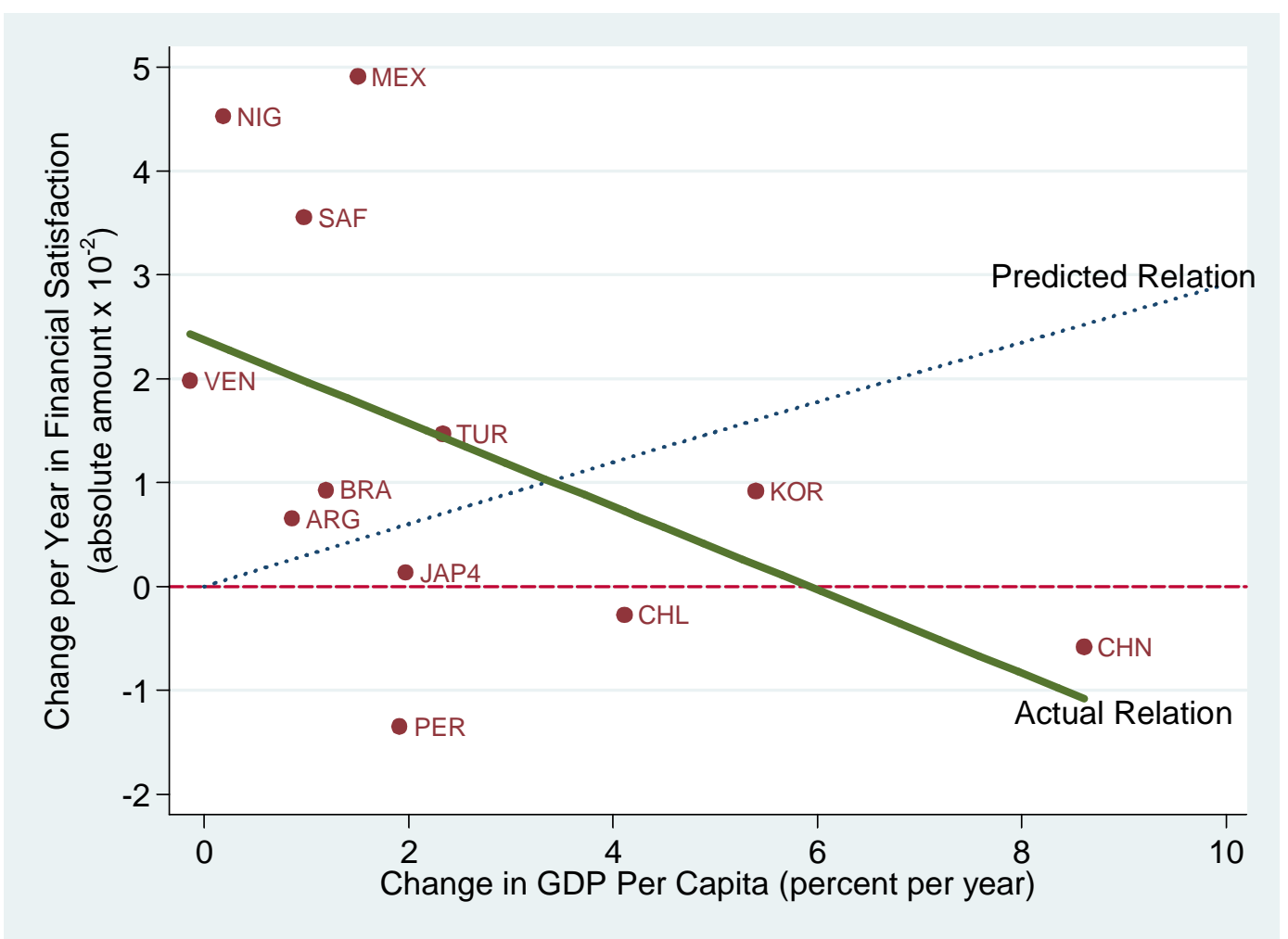

Source: Table 2, cols. 4 and 5; regression statistics, Table 6. 


\section{References}

Belson, W. A. (1966). "The Effects of Reversing the Presentation Order of Verbal Rating Scales," Journal of Advertising Research, 6, 30-37.

Bruni, L., and Pier L. P. (2005). Economics and Happiness: Framing the Analysis. Oxford, UK: Oxford University Press.

Cantril, Hadley. (1965). The Pattern of Human Concerns. New Brunswick, NJ: Rutgers University Press.

Chan, J. C. (1991). "Response-Order Effects in Likert-Type Scales," Educational and Psychological Measurement, 51, 531-540.

Clark, A.E., Frijters, P., and Shields, M.A. (2008). "Relative Income, Happiness, and Utility: An Explanation for the Easterlin Paradox and Other Puzzles," Journal of Economic Literature, 46(1), 95-144.

Commission on Growth and Development (2008). The Growth Report: Strategies for Sustained Growth and Inclusive Development. Washington, DC: The World Bank.

Di Tella, R., MacCulloch, R. J., and Oswald, A. J. (2001). "Preferences over Inflation and Unemployment: Evidence from Surveys of Happiness," American Economic Review, 91, 335341.

Easterlin, R. A. (1974). "Does Economic Growth Improve the Human Lot?" In Paul A. David and Melvin W. Reder (eds.) Nations and Households in Economic Growth: Essays in Honor of Moses Abramovitz. New York: Academic Press.

Easterlin, R. A. (2005). "Feeding the Illusion of Growth and Happiness: A Reply to Hagerty and Veenhoven," Social Indicators Research, 74(3), 429-443.

Easterlin, R. A. (2009 forthcoming). "Lost in Transition: Life Satisfaction on the Road to Capitalism," Journal of Economic Behavior and Organization. An earlier version appeared as IZA Discussion Paper 3409.

Easterlin, R. A. and Plagnol, A. C. (2008 forthcoming). "Life satisfaction and economic conditions in East and West Germany pre- and post-unification," Journal of Economic Behavior and Organization.

Easterlin, R. A., and Sawangfa, O. (2009). "Happiness and Domain Satisfaction: Theory and Evidence." In Amitava Krishna Dutt and Benjamin Radcliff (eds.) Happiness, Economics, and Politics: New Lessons for Old Problems. Northhampton, MA: Edwards Elgar Publishers. An earlier version appeared as IZA Discussion Paper 2584.

Easterly, W. (1999). "Life during Growth,” Journal of Economic Growth, 4(3), 239-275. 
European Bank for Reconstruction and Development (2007). "People in Transition," Transition Report 2007. London: European Bank for Redevelopment.

Frey, B. S., and Stutzer, A. (2002). Happiness and Economics: How The Economy and Institutions Affect Well-Being. Princeton, NJ: Princeton University Press.

Hagerty, M. R., and Veenhoven, R. (2003). "Wealth and Happiness Revisited - Growing National Income Does go with Greater Happiness," Social Indicators Research, 64, 1-27.

Hagerty, M. R., and Veenhoven, R. (2006). "Rising Happiness in Nations 1946-2004: A Reply to Easterlin," Social Indicators Research, 76, 421-436.

Helliwell, J.F. and Putnam, R.D. (2004). "The Social Context of Well-Being" Phil. Trans. R. Soc. Lond. B, 359, 1435-1446.

Heston, A., Summers, R., and Aten, B. (2006, September). Penn World Table Version 6.2. Center for International Comparisons of Production, Income and Prices, University of Pennsylvania. (URL: http://pwt.econ.upenn.edu/php_site/pwt_index.php accessed on February $\underline{14}, 2008)$

Hirata, J. (2001). "Happiness and Economics: Enriching Economic Theory with Empirical Psychology," Unpublished Master thesis, Maastricht University, Maastricht.

Kusago, T. (2007). "Rethinking of Economic Growth and Life Satisfaction in Post-WWII Japan - A Fresh Approach,” Social Indicators Research, 81, 79-102.

Layard, R. (2005). Happiness: Lessons from a New Science. New York: Penguin Press.

Lelkes, O. (2006). “Tasting Freedom: Happiness, Religion and Economic Transition,” Journal of Economic Behavior and Organization, 59, 173-194.

Møller, V. (1998). "Quality of Life in South Africa: Post-Apartheid Trends," Social Indicators Research, 43, 27-68.

Møller, V. (2001). "Happiness Trends under Democracy: Where will the New South African Setlevel Come to Rest?" Journal of Happiness Studies, 2, pp. 33-53.

Møller, V. (2007). "Researching Quality of Life in A Developing Country: Lessons from the South Africa Case." In Gough, I. and McGregor, J.A. (eds.) Wellbeing in Developing Countries: From Theory to Research. Cambridge: Cambridge University Press, pp. 242-258.

Saris, W.E., Andreenkova, A., (2001). "Following Changes in Living Conditions and Happiness in Post Communist Russia: the Russet Panel," Journal of Happiness Studies 2(2), 95-109. 
Saris, W.E., Veenhoven, R., Scherpenzeel, A.C., Bunting, B. (eds) (1995). A Comparative Study of Satisfaction with Life in Europe. Budapest: Eötvös University Press.

Schuman, H., and Presser, S. (1981). Questions and Answers in Attitude Surveys: Experiments on Question Form, Wording and Context. New York: Academic Press.

Stevenson, B., and Wolfers, J. (2008). "Economic Growth and Subjective Well-Being:

Reassessing the Easterlin Paradox," IZA Discussion Paper 3654, Institute for the Study of Labor.

Van Praag, B. M. S., and Ferrer-i-Carbonell, A. (2004) Happiness Quantified: A Satisfaction Calculus Approach. Oxford, UK: Oxford University Press.

Veenhoven, R. (2001). “Are the Russians as Unhappy as They Say They Are?” Journal of Happiness Studies, 2(2), 111-136.

World and European Values Surveys Four Wave Integrated File, 1981-2004, v.20060423, 2006. World Value Survey Association (www.worldvaluessurvey.org) and European Values Study Foundation (www.europeanvalues.nl).

World Development Indicators. World Bank. Retrieved from February 26, 2008 to June 11, 2008 from http://go.worldbank.org/IW6ZUUHUZ0.

World Values Survey 2005 Official Data File, v.20081015, 2008. World Values Survey Association (www.worldvaluessurvey.org). Aggregate File Producer: ASEP/JDS, Madrid. 
Appendices A, B and C are available at http://www-rcf.usc.edu/ easterl/articles.html. 